Klaudia Soboń

\title{
ŚWIADECTWA POLSKIEJ KULTURY NA BIAŁORUSI
}

Republika Białorusi jest niewątpliwie jednym z większych skupisk Polaków poza granicami własnego państwa. Nic więc dziwnego, że istnieje wiele świadectw polskiej kultury na terytorium naszego sąsiada. Wszelkie przejawy polskości są do dziś tematem kontrowersyjnym, pojawia się wiele twierdzeń, jakoby władze dzisiejszej Białorusi dążyły do wtopienia Polaków w społeczność białoruską i utrudniały ich działalność kulturalną. Mimo tego do dziś na terenie Białorusi istnieją polskie organizacje, stowarzyszenia i kluby, które są miejscem krzewienia i popularyzacji języka i kultury polskiej. Możemy też odnaleźć wiele miejsc pamięci, świadczących o przebywaniu Polaków na tym obszarze w dziejach historii.

Aby omówić ten temat i zrozumieć obecność tak licznej grupy Polaków w dzisiejszej Republice Białorusi, należy najpierw sięgnąć do źródeł wspólnej historii obu państw. Przez setki lat ziemie Białorusi podlegały niemal całkowitemu spolonizowaniu. Proces ten rozpoczął się od unii w Krewie w 1385 roku. Następnie przyjęcie chrześcijaństwa w 1387 roku doprowadziło do początków osadnictwa polskiego na Białorusi. Władysław Jagiełło obdarzył bojarów litewskich - którzy przyjęli chrześcijaństwo - przywilejem zapewniającym własność majątkową i wiele innych swobód, co prowadziło do ich polonizacji. Na te tereny zaczęli również przybywać przedstawiciele polskiego duchowieństwa, żołnierze i urzędnicy, a Kościół katolicki stał się ambasadorem polskiej kultury ${ }^{1}$.

${ }^{1}$ B. Chmieliński, Stowarzyszenie Polska - Biatoruś w ksztattowaniu polsko-biatoruskich stosunków 1992-2006, Warszawa 2006, s. 20-22. 
Później, po zawarciu w 1569 roku unii lubelskiej, Polska i Wielkie Księstwo Litewskie utworzyły Rzeczpospolitą Obojga Narodów, w której po pewnym czasie Korona Królestwa Polskiego przejęła dominację, co poskutkowało polonizacją szlachty białoruskiej. Niedługo po tym, w 1596 ro$\mathrm{ku}$, została podpisana unia brzeska, mająca na celu zjednoczenie Kościoła katolickiego i prawosławnego oraz podporządkowanie go papieżowi ${ }^{2}$. Jak pisze T. Kruczkowski, wprowadzenie unii nie wywarło dużego sprzeciwu w społeczeństwie Białorusi, a w XVII wieku obszary te stały się niemal całkowicie greckokatolickie. Zauważalne było, szczególnie w zachodniej części Białorusi, przenikanie żywiołu polskiego, a to prowadziło do przemian świadomości Białorusinów ${ }^{3}$. Jednakże unia była również źródłem konfliktów na dawnych terenach Rzeczypospolitej, co doprowadziło do osłabnięcia jej pozycji i dało Rosji możliwość ingerowania w jej sprawy wewnętrzne.

Rzeczpospolita jeszcze w II połowie XVIII wieku zdołała wprowadzić pewne reformy, z czego najważniejszą była Konstytucja 3 Maja z 1791 roku, która znosiła podział na Koronę i Wielkie Księstwo Litewskie. W tamtym momencie nie miało to jednak większego znaczenia, ponieważ dokonane przez Rosję, Prusy i Austrię rozbiory zakończyły swobodny rozwój ziem polskich, a po III rozbiorze w 1795 roku całość ziem białoruskich przeszła we władanie Rosji. Aczkolwiek, pomimo postępującej likwidacji wpływów polskich, jeszcze do wybuchu powstania listopadowego polskość i język polski dominowały na tych terenach. Dopiero po upadku powstania zlikwidowano polskie szkolnictwo i zaprzestano nauki języka polskiego, a tamtejszą ludność zaczęto rusyfikować. Po I wojnie światowej na mocy traktatu ryskiego podzielono tereny Białorusi pomiędzy Polskę i Rosję bolszewicką. W skład państwa polskiego weszły tereny zachodniej Białorusi, na których zamieszkiwało około 600 tysięcy Polaków, co dało szansę na powtórną polonizację miejscowej ludności ${ }^{5}$.

Wszystko zmieniło się 17 września 1939 roku, kiedy to wojska ZSRR wkroczyły na terytorium Polski pod hasłem jednoczenia ziem białoruskich

${ }^{2}$ Ibidem, s. 24.

${ }^{3}$ T. Kruczkowski, Polacy na Biatorusi na tle historii $i$ wspótczesności, Гоупп „Слонимская типография" 2003, s. 100-101.

${ }^{4}$ Ibidem, s. 104-106.

${ }^{5}$ B. Chmieliński, Stowarzyszenie Polska - Biatoruś..., op. cit., s. 30. 
i ukraińskich i wyznaczyły granicę zgodnie z paktem Ribbentrop - Mołotow. Nowe granice nie miały nic wspólnego ze strukturą narodowościową, a były jedynie umową między Stalinem i Hitlerem, w związku z czym w skład Białorusi Radzieckiej weszły ziemie całkowicie zamieszkiwane przez Polaków lub ze znaczną ich przewagą ${ }^{6}$. Rozpoczęło to etap sowietyzacji wszelkich sfer życia społecznego, m.in. zlikwidowano polskie szkolnictwo i upaństwowiono zakłady. W 1944 roku zaczęto przesiedlać ludność obu narodowości, co było skutkiem umowy pomiędzy BSRR a Polskim Komitetem Wyzwolenia Narodowego o wzajemnej repatriacji ludności. Był to czas, który wywarł ogromny wpływ na ludność białoruską i dalsze losy tej republiki. Mikołaj Iwanow pisał:

Oficjalną politykę władz wobec polskiej mniejszości na Białorusi cechował w okresie powojennym wyraźny pragmatyzm. Miejscowa administracja działała według zasady: Na Białorusi nie ma Polaków, są jedynie spolszczeni Białorusini i im wcześniej uda nam się przywrócić tych Polaków na białoruskość, tym lepiej’.

Dopiero od roku 1987, czyli od czasów pierestrojki, rozpoczęło się polskie, ale i białoruskie odrodzenie narodowe. Widać tu wyraźnie, że pomimo wcześniejszych prób rusyfikacji czy też białorusyfikacji młodego pokolenia oraz trudności w przekazywaniu i pielęgnowaniu polskiej kultury polskość zachowała się na ziemiach współczesnej Białorusi.

Białoruś odzyskała swoją niepodległość dopiero w sierpniu 1991 roku, a Polska uznała ten fakt $\mathrm{w}$ grudniu tego samego roku, po wcześniejszym podpisaniu polsko-białoruskiej „Deklaracji o dobrym sąsiedztwie, wzajemnym zrozumieniu i współpracy”. Natomiast oficjalne nawiązanie dyplomatycznych stosunków pomiędzy tymi państwami nastąpiło 2 marca 1992 roku. Bardzo istotnym dokumentem we wzajemnych stosunkach jest podpisany 23 czerwca 1992 roku „Traktat między Rzecząpospolitą Polską a Republiką Białoruś o dobrym sąsiedztwie i przyjaznej współpracy”, który gwarantuje m.in. prawa dla mniejszości narodowych, tj. zakładanie organizacji, wyznawanie własnej religii, prawo do swobodnego wyrażania tożsamości czy też prawo nauczania języka ojczystego ${ }^{8}$.

\footnotetext{
${ }^{6}$ T. Kruczkowski, Polacy na Biatorusi..., op. cit., s. 129-130.

${ }^{7}$ M. Iwanow, Polacy w Zwiazku Radzieckim 1917-1990, [w:] Polacy w Kościele katolickim w ZSRR, ks. E. Walewander (red.), Lublin 1991, s. 79.

${ }^{8}$ B. Chmieliński, Stowarzyszenie Polska - Biatoruś..., op. cit., s. 52-56.
} 


\section{Mniejszość polska na Białorusi}

Gdy spojrzeć na przebieg historii, nie zaskakuje obecność licznej grupy Polaków na ziemiach dzisiejszej Białorusi, która to jest drugą po Rosjanach największą mniejszością narodową na tych terenach. Natomiast wraz ze zmianami sytuacji politycznej można zauważyć również zmiany w liczbie ludności deklarującej polską przynależność narodową. Sowiecki spis powszechny, przeprowadzany w 1989 roku, w warunkach pieriestrojki i przebudzenia tożsamości różnych grup narodowych, zamieszkujących Związek Radziecki, wykazał w Białoruskiej Republice prawie 418 tysięcy Polaków. Pierwszy spis niepodległej Białorusi z 1999 roku - już tylko około 396 tysięcy. Drastyczny spadek ludności polskiej unaoczniły wyniki ostatniego spisu z roku 2009 - na Białorusi jedynie 294,5 tysiąca obywateli zadeklarowało polską narodowość. Jednakże według danych kościelnych na tych terenach może mieszkać nawet około miliona osób polskiej narodowości'.

Tabela 1. Polacy na Białorusi według spisów powszechnych w latach 1959-2009

\begin{tabular}{|l|c|}
\hline Rok & Liczebność \\
\hline 1959 & 538881 \\
\hline 1970 & 382600 \\
\hline 1979 & 403169 \\
\hline 1989 & 417720 \\
\hline 1999 & 395712 \\
\hline 2009 & 294549 \\
\hline
\end{tabular}

Źródło: Opracowanie własne na podstawie H. Giebień, Działalność Zwiqazku Polaków na Biatorusi w latach 1987-2005 na tle sytuacji spoteczno-politycznej w Biatoruskiej Socjalistycznej Republice Radzieckiej / Republice Biatorus, Wrocław 2014, s. 39.

${ }^{9}$ H. Giebień, Dziatalność Zwiazku Polaków na Biatorusi w latach 1987-2005 na tle sytuacji spoteczno-politycznej w Biatoruskiej Socjalistycznej Republice Radzieckiej / Republice Biatoruś, Wrocław 2014, s. 37-39. 
Dokładne określenie liczby Polaków na terenie Republiki Białoruś jest zadaniem bardzo trudnym. Kwestią zasadniczą, dotyczącą informacji o spadającej liczbie Polaków, mogą być fałszerstwa powszechnych spisów ludności, różnorodność kryteriów liczenia i metod przeprowadzania spisów, co sygnalizowali polscy działacze podczas przeprowadzania spisu w 2009 roku. Są to zagadnienia budzące wątpliwości w zakresie wiarygodności przedstawionych danych.

Kolejnymi elementami prowadzącymi do takiej sytuacji mogą być: białorutenizacja Kościoła rzymskokatolickiego; podział Związku Polaków na Białorusi, co w konsekwencji pogorszyło relacje na linii Polska - Białoruś; polityka depolonizacyjna władz białoruskich czy też po prostu zwiększenie zainteresowania kulturą białoruską lub rosyjską wśród młodego pokolenia. Jeżeli brać pod uwagę rozmieszczenie Polaków według obwodów Białorusi, niezmiennie od lat obwód grodzieński jest największym skupiskiem ludności polskiego pochodzenia - według spisu z 2009 roku w tym obwodzie mieszka 230810 Polaków. Kolejno jest to obwód miński (17 908) i obwód brzeski (17 539) ${ }^{10}$. W związku z tak liczną grupą Polaków w Grodnie od lat jest to miejsce, gdzie najbardziej uwidacznia się działalność mniejszości polskiej na rzecz wzmocnienia tożsamości narodowej, krzewienia polskiej kultury, znajomości języka ojczystego poprzez tworzenie przeróżnych inicjatyw i wydarzeń czy też poprzez zrzeszanie się w kluby i stowarzyszenia.

\section{Organizacje i szkolnictwo polskie w Republice Białorusi}

Mimo usilnych prób wyparcia polskości na terenach Białorusi, Polacy są świadomi swojego pochodzenia i zachowało się $\mathrm{w}$ nich poczucie świadomości narodowej oraz potrzeba rodzimego języka, co uwidacznia się poprzez kultywowanie tradycji narodowych i religijnych. Jak już wspomniano, po upadku ZSRR i odzyskaniu niepodległości przez Białoruś mniejszości narodowe uzyskały również możliwość instytucjonalizowania się, m.in. poprzez powoływanie stowarzyszeń, co pomogło w odrodzeniu polskiej kultury.

${ }^{10}$ Ibidem, s. 41. 
Pierwszymi organizacjami, jakie powstały w momencie odradzania narodowego, były: Polskie Stowarzyszenie Kulturalno-Oświatowe im. Adama Mickiewicza i Mińskie Towarzystwo „Polonia”, a także inne, mniejsze kluby lokalne, które już 16 czerwca 1990 roku zostały przekształcone w organizację z siedzibą w Grodnie o nazwie Związek Polaków na Białorusi (ZPB). Oficjalne zarejestrowanie związku nastąpiło 25 lutego 1991 ro$\mathrm{ku}$, po długich staraniach i pomimo nieprzychylności władz. Głównym celem organizacji jest wspieranie polskiego szkolnictwa, polskiej kultury, tradycji i prasy ${ }^{11}$.

W obwodach Białorusi powstają również oddziały związku, których w roku 2003 było $133^{12}$. Przy oddziałach powstają przeróżne kluby, stowarzyszenia i mniejsze organizacje, takie jak np. Klub Sportowy „Sokół”, Klub Kobiet Polskich, Stowarzyszenie Żołnierzy AK i Kombatantów, Polska Szkoła Społeczna, kluby młodzieży polskiej, koła twórców ludowych, zespoły taneczne, chóry i polskie drużyny harcerskie. ZPB od początku swojego istnienia troszczy się o odrodzenie tradycji zarówno religijnych, jak i państwowych. Dzięki temu Polacy na Białorusi świętują takie rocznice jak: Konstytucja 3 Maja, Święto Niepodległości oraz inne święta narodowe i religijne.

Związek wspiera również polskie media. Wydawane są: dwutygodnik „Słowo Życia”, miesięczniki „Magazyn Polski” i „Głos znad Niemna” oraz kwartalnik „Echa Polesia”. Oprócz tego działają internetowe portale informacyjne: Znadniemna.pl, Redakcja Białoruska Kresy24.pl, portal Echa Polesia oraz polska audycja radiowa Znad Niemna $i$ Berezyny na falach Radia Racyja ${ }^{13}$.

Priorytetową sprawą dla związku było od początku odrodzenie polskiego szkolnictwa, które we wcześniejszych latach zostało całkowicie zlikwidowane. Dzięki usilnym staraniom ZPB i wsparciu polskiego rządu powstały dwie polskojęzyczne szkoły średnie: w Grodnie - działająca od 1996 roku, oraz w Wołkowysku - działająca od 1992 roku. Poza tym języka polskiego można się było uczyć np. w szkółkach sobotnio-niedzielnych funkcjonujących przy parafiach i Domach Polskich, w przedszkolach,

\footnotetext{
${ }^{11}$ Ibidem, s. 76.

12 Ibidem, s. 89.

${ }^{13}$ Polska Platforma Medialna na Białorusi, http://wid.org.pl/polska-platforma-medialna-nabialorusi (dostęp: 27.03.2017).
} 
a także w szkołach, gdzie język polski wykładany był jako oddzielny przedmiot $^{14}$. Nie świadczy to jednak o tym, że polskie szkolnictwo znajduje się $\mathrm{w}$ dobrym stanie. Istotnym problem jest chociażby brak podręczników w języku polskim i wykwalifikowanej kadry nauczycielskiej. Niestety, za prezydentury Aleksandra Łukaszenki nie zostało wydane żadne pozwolenie na wybudowanie polskiej szkoły. Fakt niewystawienia pozwolenia na budowy szkół polskich w Nowogródku i Werenowie - miejscach dużego skupiska Polaków - świadczy o niezbyt przychylnym podejściu władz białoruskich do mniejszości polskiej. Z kolei na początku 2017 roku pojawił się projekt, który uderza w już istniejące polskie szkoły. Białoruskie Ministerstwo Edukacji chce przekształcić szkoły polskie, działające na Białorusi, w szkoły dwujęzyczne. W projekcie napisano, że w klasach, w których nauka odbywa się w językach mniejszości narodowych, takie przedmioty jak historia Białorusi, historia świata, wiedza o społeczeństwie, człowiek i świat oraz geografia mają odbywać się w językach urzędowych Białorusi, a więc po rosyjsku lub białorusku, a nie, jak w przypadku polskich szkół - po polsku ${ }^{15}$. ZPB podjęło kroki, aby nie dopuścić do wejścia tego postulatu w życie, jako że uderza on bezpośrednio w tamtejszych Polaków, a co więcej - łamie założenia Konstytucji RB.

Obecnie, mimo rozłamu, $\mathrm{ZPB}^{16}$ wciąż pozostaje organizacją ważną w świadomości polskiej mniejszości, zrzeszającą około 30 tysięcy osób ${ }^{17}$. Aczkolwiek oprócz Związku Polaków na Białorusi powstały też inne organizacje zrzeszające Polaków, z których najprężniej działającymi są: Zjednoczenie Społeczne „Polska Macierz Szkolna” i Republikańskie Społeczne Zjednoczenie „Harcerstwo”.

${ }^{14}$ H. Giebień, Działalność Zwiazku Polaków na Biatorusi..., op. cit., s. 274-275.

${ }^{15}$ Tak wyglada „przyjaźn z Eukaszenkq”! Koniec szkót polskich na Biatorusi!, http://kresy24. pl/tak-wyglada-przyjazn-z-lukaszenka-koniec-szkol-polskich-na-bialorusi-wideo (dostęp: 27.03.2017).

${ }^{16}$ Związek podzielił się po VI Zjeździe w marcu 2005 roku w Grodnie. Od momentu rozłamu, na skutek konfliktów wewnętrznych i ingerencji władz Białorusi, istnieją dwa związki - uznawany przez władze białoruskie, na czele z Mieczysławem Łysym, i drugi, nieuznawany przez władze Białorusi, nazywany nielegalnym, natomiast uznawany przez władze polskie, na czele $z$ Andżeliką Borys. Po rozbiciu pozycja związku została osłabiona, ale mimo to cały czas widać pracę ZPB na rzecz mniejszości polskiej.

${ }^{17}$ H. Giebień, Działalność Związu Polaków na Biatorusi..., op. cit., s. 89. 
„Polska Macierz Szkolna” z siedzibą w Grodnie została reaktywowana na terenie Białorusi 3 grudnia 1995 roku. Wcześniej funkcjonowała jako Towarzystwo Przyjaciół Polskiej Szkoły przy ZPB. Już wtedy znacznie przyczyniła się do popularyzacji nauki języka polskiego i do założenia polskich szkół na terenie Białorusi - w Grodnie i Wołkowysku. Głównym celem organizacji jest „szerzenie oświaty polskojęzycznej na terenie Białorusi w duchu narodowym, chrześcijańskim i obywatelskim"18 oraz całość zadań dążących do wspierania nauczycieli, nauczania w języku polskim, a także szeroko pojmowana działalność kulturalna. ZSPMS posiada, podobnie jak $\mathrm{ZPB}$, oddziały $\mathrm{w}$ innych miastach oraz jednostki takie jak: Uniwersytet Trzeciego Wieku, Klub Kobiet „Grodnianka”, Wspólnota „Młoda Polonia”, Klub Studentów Polskich i Liceum Społeczne im. E. Orzeszkowej. Działalność „Polskiej Macierzy Szkolnej” jest także wspierana przez Senat RP, Ministerstwo Edukacji Narodowej RP i organizacje pozarządowe, m.in. Stowarzyszenie „Wspólnota Polska”19.

Związek Harcerstwa Polskiego istnieje na Białorusi od 1989 roku, a po ponownym zarejestrowaniu w 2000 roku funkcjonuje jako Republikańskie Społeczne Zjednoczenie „Harcerstwo”. Od początku istnienia działalność harcerstwa bardzo dobrze i sukcesywnie się rozwijała. Powstały drużyny żeńskie, męskie i drużyny zuchów. ZHP aktywnie współpracuje też ze środowiskami polskimi ze Wschodu i Zachodu, dzięki czemu możliwe są wszelakie obozy i wymiany młodzieży. Celem RSZ „Harcerstwo" jest wychowanie dzieci i młodzieży w duchu religijnym i patriotycznym na świadomych obywateli kraju, którzy pamiętają o przeszłości i dysponują wiedzą na temat swojego pochodzenia dzięki nauce języka polskiego, historii i znajomości polskich tradycji, ale także znają historię ziem, na których mieszkają. Jednym z zadań harcerzy jest poszukiwanie polskich grobów, szczególnie żołnierzy poległych w I i II wojnie świato$w^{20}{ }^{20}$. Podobnie jak w przypadku „Polskiej Macierzy Szkolnej”, „Harcerstwo" również wspierane jest - właściwie od początku działalności - przez Stowarzyszenie „Wspólnota Polska”, które finansowało obozy letnie, zakup mundurów i inne elementy wyposażenia harcerzy.

\footnotetext{
${ }^{18}$ Polska Macierz Szkolna, http://pmsgrodno.org/pms (dostęp: 09.04.2017).

${ }^{19}$ Ibidem.

${ }^{20}$ H. Giebień, Działalność Zwiazku Polaków na Biatorusi..., op. cit., s. 253-254.
} 
Do 2005 roku Związek Polaków na Białorusi był zdecydowanie organizacją wiodącą prym wśród polskiej mniejszości. Od początku istnienia angażował się we wszelkie sprawy dotyczące Polaków, a powstające przy nim mniejsze struktury organizacyjne pozwalały na rozbudzanie tożsamości narodowej i rozwój środowisk polskich we wszelkich dziedzinach. Jednak ZPB poprzez swoje wewnętrzne konflikty znacznie osłabł i istnieje prawdopodobieństwo, że to właśnie Zjednoczenie Społeczne „Polska Macierz Szkolna” i Republikańskie Społeczne Zjednoczenie „Harcerstwo” staną się liderami polskiego ruchu. Obie te organizację mają osobowość prawną i działają niezależnie od ZPB, dzięki czemu konflikt w strukturach związku nie wpłynął na ich funkcjonowanie. Co więcej, jeśli weźmie się pod uwagę kierunki ich działania, będą dalej samodzielnie dokładać starań na rzecz rozwoju polskiej kultury, tradycji czy oświaty na ziemiach Białorusi.

\section{Miejsca pamięci}

Od momentu powstania Związku Polaków na Białorusi, oprócz pracy na rzecz rozwoju polskiej oświaty, priorytetową sprawą jest troska o miejsca pamięci narodowej i kulturowej. Szczególnie ważna, poza obchodzeniem polskich świąt czy rocznic państwowych, jest opieka nad cmentarzami i mogiłami, które świadczą o obecności Polaków na tych terenach. Nie chodzi tu tylko o składanie hołdu poległym bohaterom poprzez odwiedzanie grobów, ale również o remontowanie i sprzątanie cmentarzy.

Na stronie internetowej Ambasady RP w Mińsku możemy znaleźć wykaz polskich kwater, cmentarzy i grobów - które są miejscami spoczynku żołnierzy Wojska Polskiego - wraz ze zdjęciami, nazwiskami i datami śmierci poległych ${ }^{21}$. Nie jest to jeszcze pełna lista, natomiast będzie ona systematycznie uzupełniana. ZPB mocno się starał, aby zachęcić miejscowych Polaków do współdziałania przy pracach remontowych i uporządkowywaniu tych nekropolii. Wskutek tego na wojskowych cmentarzach

\footnotetext{
${ }^{21}$ Zob. Miejsca Pamięci Narodowej, http://www.minsk.msz.gov.pl/pl/informacje_konsular-
} ne/mpn (dostęp: 11.04.2017). 
z powodzeniem przeprowadzane są coroczne wiosenne akcje porządkowe, w których biorą udział nie tylko członkowie związku i innych organizacji, ale i tamtejsza polska społecznośćc ${ }^{22}$.

Równie ważną inicjatywą w tym zakresie jest regularne remontowanie cmentarzy. Co ciekawe, powstała nieformalna grupa polskich działaczy o nazwie „Polacy na Kresach Wschodnich”, która już od około 2 lat zajmuje się renowacją polskich kwater wojskowych na terenach dzisiejszej Białorusi $^{23}$. I tak na przykład $\mathrm{w}$ ostatnim czasie, we współpracy $\mathrm{z}$ pracownikami Ambasady RP w Mińsku, zostały odnowione cmentarze w Użance, Brasławiu i Burakach. Zdecydowanie można stwierdzić, że takie zaangażowanie naszych rodaków żyjących na Białorusi świadczy o ich dużej świadomości tożsamości narodowej i o identyfikacji z polską kulturą i historią.

Warto w tym miejscu wspomnieć o cmentarzysku Kuropaty, które istnieje w świadomości mieszkańców Białorusi, ale też Polaków żyjących w Polsce. Jest to miejsce, gdzie spoczywają tysiące ofiar rozstrzelanych przez NKWD w latach 1937-1941 ${ }^{24}$. Temat ten ciągle nie jest do końca przebadany i nie wiadomo, jaka jest dokładnie liczba poległych. $\mathrm{Z}$ pewnością znajdują się tam mogiły zarówno Białorusinów, jak i Polaków pochodzących z terytoriów II Rzeczypospolitej. Większość znaków pamięci pojawiało się tam $z$ inicjatywy ludzi, którzy przynosili w to miejsce krzyże. Nie jest to więc do końca zapomniane miejsce. Kuropaty odwiedzane są przez Polaków, polskie władze i ambasadorów oraz Białorusinów, którzy chcą, aby cmentarzysko zostało należycie potraktowane. Niestety, choć jest to także ważne miejsce pamięci narodowej Białorusinów, nie doczekało się dotychczas upamiętnienia ze stron białoruskiej władzy, co więcej - miała tamtędy przebiegać obwodnica, która zniszczyłaby część mogił. Jednak udało się temu zapobiec dzięki protestom młodych ludzi ${ }^{25}$. Dopiero w marcu bieżącego roku Aleksander Łukaszenka oznajmił, że powstanie tam zespół memorialny:

${ }^{22}$ H. Giebień, Działalność Zwiqzzku Polaków na Biatorusi..., op. cit., s. 266.

${ }^{23}$ Polacy na Kresach Wschodnich na straży mogit bohaterów, http://nowe.kresy.pl/wydarzenia/ polacy-na-kresach-wschodnich-na-strazy-mogil-bohaterow-foto (dostęp: 11.04.2017).

${ }^{24}$ E. Ziółkowska, Kuropaty, „Biuletyn Instytutu Pamięci Narodowej” 2009, nr 1-2, s. 48.

${ }^{25}$ Ibidem, s. 52-53. 
Poleciłem stworzyć odpowiedni memoriał, nie gigantyczny, nie twierdzę brzeską. Obecnie trwa konkurs. Zrobimy ten memoriał, być może będzie to coś w rodzaju niedużej kaplicy ${ }^{26}$.

Jest to decyzja, na którą z niecierpliwością czekały środowiska polskie i białoruskie, pragnące należytego utrwalenia Kuropat $\mathrm{w}$ dziejach historii i w świadomości ludzi.

Cofając się bardziej w głąb historii, można na Białorusi odnaleźć pamiątkę jeszcze $z$ czasów I Rzeczypospolitej. Jest to zespół zamkowo-pałacowy, będący dawną rezydencją Radziwiłłów, oraz ich rodowy cmentarz w Nieświeżu, znajdujący się w podziemiach kościoła pw. Bożego Ciała, będącego pierwszą barokową budowlą na wschodzie Europy. Spoczywają tam szczątki około 80 przedstawicieli tego rodu, a ostatni pochówek miał miejsce w 2000 roku. W tej części Europy jest to jedyna taka nekropolia, którą często porównuje się z kryptą Habsburgów w Wiedniu. W 2005 roku została wpisana na Listę Dziedzictwa UNESCO ${ }^{27}$.

Ciekawą inicjatywą, która upamiętni wspólne dzieje Polaków i Białorusinów, jest zatwierdzony $\mathrm{w}$ tym roku projekt o powstaniu w centrum Grodna tabliczek $\mathrm{z}$ dawnymi nazwami ulic, również tych $\mathrm{z}$ czasów II Rzeczypospolitej. Przedsięwzięcie to było zainicjowane przez mieszkańców Grodna, którzy wystosowali do władz miasta odpowiednią petycję. W pierwszym etapie uzgodniono 16 ulic, a łącznie będą to 43 ulice, na których pojawią się tablice przedstawiające chronologicznie, jak na przestrzeni wieków zmieniały się ich nazwy. Przykładowo będzie można się dowiedzieć, że obecna ulica Lenina to dawna Piłsudskiego. Wstępnie nazwy ulic zapisane będą po białorusku, jednak możliwe, że pojawi się też zapis łaciński ${ }^{28}$. Podobne rozwiązanie wejdzie w życie $\mathrm{w}$ Mińsku, i co ciekawe - władze wcale nie sprzeciwiały się takiemu pomysłowi, wręcz przeciwnie, uważają, że wpływa to pozytywnie na atrakcyjność turystyczną miasta.

${ }^{26}$ Eukaszenka o upamiętnieniu ofiar NKWD w Kuropatach. „Polecitem stworzyć odpowiedni memoriat”, http://wpolityce.pl/swiat/332896-lukaszenka-o-upamietnieniu-ofiar-nkwd-w-kuropatach-polecilem-stworzyc-odpowiedni-memorial (dostęp: 12.04.2017).

${ }^{27}$ C. Rudziński, Nieśwież. Rodowa nekropolia Radziwittów, http://www.krajoznawcy.info.pl/ rodowa-nekropolia-radziwillow-26554 (dostęp: 12.04.2017).

${ }^{28}$ Grodno: pojawiq się tablice $z$ historycznymi nazwami ulic, http://www.polskieradio.pl/75/921/ Artykul/1721124,Grodno-pojawia-sie-tablice-z-historycznymi-nazwami-ulic (dostęp 12.04.2017). 
Nie można także zapomnieć o miejscach pamięci związanych z kulturą, czyli takich, które upamiętniają artystów powiązanych z ziemią białoruską, ale są również ważni w świadomości Polaków. Na terenie Białorusi zachowały się m.in. pałacyk i dworek Wańkowiczów, dom Moniuszków oraz dom Mickiewicza. Organizowane są wycieczki szlakiem Adama Mickiewicza i Elizy Orzeszkowej ${ }^{29}$.

Ważnym wydarzeniem było odsłonięcie w 2003 roku pomnika Adama Mickiewicza w Mińsku i nazwanie skweru jego imieniem. W uroczystości wzięło udział wielu mieszkańców Mińska, jak również przedstawiciele władz białoruskich i goście z Polski. Co więcej, miejscowe władze odniosły się pozytywnie do tego, aby na cokole powstał napis zarówno po polsku, jak i po białorusku. Może dlatego, iż bardzo często podkreślane jest, że Mickiewicz był polskim poetą piszącym po polsku, ale silnie związanym z terenami współczesnej Białorusi, co potwierdza jego twórczość. Od momentu powstania pomnika corocznie oddział ZPB w Mińsku, wraz z proboszczem parafii św. Szymona i Heleny, organizuje w tym miejscu wspólne kolędowanie $\mathrm{w}$ dniu urodzin poety, które przypadają w Wigilię Bożego Narodzenia ${ }^{30}$. Wczé́niej, z okazji 200. rocznicy urodzin A. Mickiewicza, w 1998 roku odsłonięto w Grodnie pomnik-popiersie przy Domu Polskim ${ }^{31}$.

Kolejną wybitną postacią, żyjącą w pamięci obu narodów, jest Eliza Orzeszkowa, która przez całe życie związana była z Grodzieńszczyzną. Pojawia się tu podobna kwestia, jak przy A. Mickiewiczu: Orzeszkowa uznawana jest za polską pisarkę, ale nie można zaprzeczyć, że jej twórczość świadczy o więzi z terenami współczesnej Białorusi. W związku z tym już od 1995 roku ZPB i działający przy nim Komitet Pamięci Elizy Orzeszkowej silnie angażowały się w przywrócenie Muzeum E. Orzeszkowej w Grodnie, w domu, w którym literatka mieszkała przez ostatnie lata przed śmiercią. Ostatecznie w 160. rocznicę jej urodzin, w 2001 roku, muzeum zostało ponownie - działało $\mathrm{w}$ dwudziestoleciu międzywojennym - uroczyście otwarte ${ }^{32}$. Można tu obejrzeć pamiątki po pisarce, ale organizowane są również spotkania tematyczne, związane z życiem i twórczo-

\footnotetext{
${ }^{29}$ H. Giebień, Dziatalność Zwiqzzu Polaków na Biatorusi..., op. cit., s. 264.

${ }^{30}$ P. Juckiewicz, Kolędowanie z Mickiewiczem, http://znadniemna.pl/13785/koledowanie-zmickiewiczem (dostęp: 12.04.2017).

${ }^{31}$ H. Giebień, Działalność Zwiazku Polaków na Biatorusi..., op. cit., s. 261.

${ }^{32}$ Ibidem, s. 260-261.
} 
ścią Elizy Orzeszkowej. W Grodnie znajduje się także pomnik z okresu międzywojennego i grób Orzeszkowej. Co roku w tych miejscach, w rocznicę śmierci pisarki, Polacy i Białorusini licznie składają kwiaty w hołdzie pamięci tej wybitnej postaci.

Równie znakomitą postacią, bliższą naszym czasom i żyjącą bardziej w pamięci Polaków, jest Czesław Niemen, pochodzący również z Grodzieńszczyzny. Urodził się w 1939 roku w Starych Wasiliszkach koło Nowogródka, na terenach leżących wtedy w granicach Polski. Początkowo śpiewał $\mathrm{w}$ chórze kościelnym, a w latach pięćdziesiątych ub. wieku uczęszczał do szkoły muzycznej w Grodnie, jednak na fali ostatnich wysiedleń Polaków z Kresów Wschodnich wyjechał do Polski, gdzie rozwijał swoją muzyczną twórczość i spędził resztę życia ${ }^{33}$. 20 lutego 2011 roku odbyło się otwarcie muzeum i odsłonięcie pamiątkowej tablicy w domu rodzinnym Niemena. Muzeum powstało dzięki staraniom miłośników artysty i mieszkańców wsi. Część ekspozycji została zrekonstruowana na podstawie zdjęć i wspomnień, natomiast część to oryginalne rzeczy $\mathrm{z}$ domu artysty, które sąsiedzi znosili do powstającej placówki. Przedmioty trafiły do niej od rodziny muzyka w momencie, kiedy ta przeprowadzała się do powojennej Polski. Muzeum pełni także rolę niejako domu kultury. Odbywają się tam spotkania i koncerty, które promują kulturę polską, ale też kulturę białoruską. Czesław Niemen nigdy nie zapomniał o swojej rodzinnej wsi i odwiedzał ją przy okazji swoich koncertów na wschodzie Europy $^{34}$. Mieszkańcy Starych Wasiliszek z pewnością też nie zapomnieli o wybitnym muzyku, i tak np. w tamtejszym kościele, w którym Niemen w dzieciństwie grał na organach, w rocznicę śmierci artysty odbywa się msza w jego intencji.

\section{Wydarzenia kulturalne}

Mówiąc o świadectwach kultury, warto wspomnieć także o wydarzeniach, jakie odbywają się w miastach Republiki Białoruś. Dają one

\footnotetext{
${ }^{33}$ M. Sienkiewicz, Czestaw Niemen, http://culture.pl/pl/tworca/czeslaw-niemen (dostęp: 10.04.2017).

${ }^{34}$ A. Banach, Stare Wasiliszki, http://andrzej-banach.eu/kresy/stare-wasiliszki (dostęp: 10.04.2017).
} 
bowiem możliwość czy to oddania hołdu wybitnym postaciom, czy też wyjścia na zewnątrz $\mathrm{w}$ celu pokazania i przybliżenia własnej kultury, pewnych narodowych wartości, ale są też po prostu przyczynkiem do integracji społeczeństwa. Oprócz wszelkich uroczystości, związanych ze świętami narodowymi czy kościelnymi i obchodami ważnych w świadomości Polaków rocznic, niezwykle ważne są też wydarzenia odnoszące się do polskiej kultury i tradycji.

I tak od 2011 roku w Grodnie odbywa się Festiwal Piosenki Polskiej, utytułowany imieniem Czesława Niemena. Organizatorem jest Zjednoczenie Społeczne „Polska Macierz Szkolna”. W festiwalu może wziąć udział młodzież w wieku od 12 do 17 lat. Uczestnicy zobowiązani są do zaprezentowania utworów z polskiego repertuaru. Celem wydarzenia jest umożliwienie młodym osobom zaprezentowania talentu, a także zapoznania się z twórczością nie tylko Niemena, ale i innych polskich wykonawców, co służy popularyzowaniu polskiej kultury. Młode pokolenie bardzo chętnie bierze udział w konkursie, dzięki czemu nawiązuje kontakt z kulturą i językiem polskim w niecodzienny i interesujący je sposób ${ }^{35}$.

Wart uwagi jest też Festiwal Piosenki im. Anny German „Eurydyka” w Mińsku. Organizowany jest od 2012 roku dzięki Ambasadzie Rzeczypospolitej Polskiej w Mińsku, przy współpracy z duetem WitaM - Maryna Towarnicka i Witalij Alieszkiewicz - oraz z Instytutem Polskim w Mińsku i Zielonogórskim Ośrodkiem Kultury. Według organizatorów celem tego projektu jest: popularyzacja twórczości artystycznej Anny German, promocja artystów amatorów, integracja polskich środowisk muzycznych na Białorusi, popularyzacja języka polskiego ${ }^{36}$. Uczestnicy konkursu śpiewają po dwie piosenki $\mathrm{z}$ repertuaru wokalistki, w tym jedną po polsku, a drugą do wyboru - po polsku lub po rosyjsku. Od 2015 roku nagrodą dla zwycięzców jest trasa koncertowa po Polsce ${ }^{37}$. Anna German była bardzo dobrze znana na obszarze byłego ZSRR, wydawała również płyty

\footnotetext{
${ }^{35}$ Polska Macierz Szkolna, http://pmsgrodno.org/pms (dostęp: 09.04.2017).

${ }^{36}$ Festiwal Piosenki im. Anny German, http://minsk.msz.gov.pl/pl/aktualnosci/festiwal_piosenki im_anny_german;jsessionid=0AB0576C0F2C70290BEC849358114DDF.cmsap2p (dostęp: 13.04.2017).

${ }^{37}$ Finat V Festiwalu Piosenki Anny German, http://www.minsk.msz.gov.pl/pl/c/MOBILE/ aktualnosci/final_v_festiwalu_piosenki_anny_german (dostęp: 13.04.2017).
} 
w języku rosyjskim, nic więc dziwnego, że festiwal cieszy się ogromną popularnością wśród amatorskich wokalistów i zespołów z całej Białorusi.

Należy również wspomnieć o Jarmarku Kaziukowym w Grodnie, który corocznie od 2002 roku organizuje Związek Polaków na Białorusi wraz z Konsulatem Generalnym RP w Grodnie. Odbywa się on zgodnie z wielowiekową tradycją, na początku marca, z okazji obchodzonego 4 marca Dnia Świętego Kazimierza ${ }^{38}$ - patrona rzemieślników i twórców ludowych $^{39}$. W Kaziukach biorą udział rzemieślnicy, twórcy ludowi, rękodzielnicy, cukiernicy, którzy podczas święta prezentują swoje wyroby. Jarmark co roku przyciąga tłumy ludzi, chcących obejrzeć czy też nabyć piękne, oryginalne przedmioty, wykonane przez artystów ludowych.

W 2016 roku zorganizowany został Festiwal Kultury Polskiej, podczas którego w centrum Mińska można było obejrzeć stroje regionalne, spróbować polskiej kuchni czy też posłuchać muzyki polskich zespołów ludowych $^{40}$. W tym samym roku odbył się również Festiwal Kultur Polskiej i Białoruskiej w Rakowie, który podobnie odnosił się do folkloru. Został zorganizowany we współpracy strony białoruskiej i polskiej. Występowały tam ludowe zespoły z obu państw, na kiermaszu można było zakupić swojskie wyroby i obejrzeć różne scenki teatralne. Organizatorzy wyrazili chęć organizowania tego festiwalu każdego roku ${ }^{41}$. $Z$ pewnością jest to krok do przybliżenia mieszkańcom Białorusi wspólnej historii, kultury i tradycji.

Przykłady wszelkich wydarzeń, imprez, spotkań czy konkursów - organizowanych chociażby przez miejscowe oddziały ZPB - można by jeszcze mnożyć. Jednakże nie to jest celem niniejszego artykułu. Istotne jest, żeby zwrócić uwagę na sam fakt, iż takie przedsięwzięcia mają na Białorusi miejsce i są obecne w życiu polskiej mniejszości, ale też częściowo i w życiu Białorusinów.

${ }^{38}$ Święty Kazimierz był synem króla Polski i Litwy Kazimierza IV Jagiellończyka, po kanonizacji został patronem obu państw.

${ }^{39}$ Kaziuki w Grodnie, http://znadniemna.pl/21526/kaziuki-2017-zwyciezyla-tradycja (dostęp: 13.04.2017).

${ }^{40}$ Festiwal Kultury Polskiej, http://polaki.org/?p=3474 (dostęp: 13.04.2017).

${ }^{41}$ Festiwal Kultur Polskiej $i$ Biatoruskiej w Rakowie, http://polaki.org/?p=3474 (dostęp: 13.04.2017). 
Spoglądając na bieg historii, można odnieść wrażenie że Polaków i Białorusinów więcej łączy niż dzieli. I nie jest to tylko krótki epizod w przeszłości, ale całe wieki wspólnej historii, mającej wpływ na dzień dzisiejszy. Burzliwa historia Europy spowodowała, że dość liczna etnicznie polska ludność pozostała w granicach dzisiejszej Republiki Białorusi, osadzając tam dużą część naszej polskiej kultury.

$\mathrm{Z}$ jednej strony zauważalny jest spadek ludności deklarującej polską tożsamość narodową, $\mathrm{z}$ drugiej zaś istniejące organizacje prężnie działają w kierunku utrwalenia wśród polskiej mniejszości świadomości pochodzenia, przekazując wiedzę na temat polskiej kultury, tradycji i historii czy też poprzez naukę języka polskiego. Pojawiają się głosy, że białoruska władza próbuje utrudniać pracę instytucji czy szkół, manifestując $\mathrm{w}$ ten sposób swoją niechęć do polskiej mniejszości i próbuje ją „białorutenizować”. Należałoby się jednak zastanowić, czy ma to skutki w rzeczywistości, czy może jest to po prostu odzwierciedleniem złych stosunków politycznych pomiędzy Polską a Białorusią. Nie można bowiem nie zauważyć, jak wiele świadectw polskiej kultury jest obecnych za naszą wschodnią granicą i że polska społeczność jest ich świadoma. Należy stwierdzić, że - pomijając sferę władz obu państw - mniejszość polska i Białorusini żyją w zgodzie, szanując swoją wspólną historię i spuściznę kulturową.

\section{Bibliografia}

Chmieliński B., Stowarzyszenie Polska - Biatoruś w ksztattowaniu polsko-biatoruskich stosunków 1992-2006, Warszawa 2006.

Giebień H., Dziatalność Zwiqzku Polaków na Biatorusi w latach 1987-2005 na tle sytuacji spoteczno-politycznej w Biatoruskiej Socjalistycznej Republice Radzieckiej I Republice Biatoruś, Wrocław 2014.

Iwanow M., Polacy w Zwiazku Radzieckim 1917-1990, [w:] Polacy w Kościele katolickim w ZSRR, ks. E. Walewander (red.), Lublin 1991.

Kruczkowski T., Polacy na Biatorusi na tle historii $i$ wspótczesności, Гоупп „Слонимская типография" 2003.

Ziółkowska E., Kuropaty, „Biuletyn Instytutu Pamięci Narodowej” 2009, nr 1-2. 
Zasoby internetowe:

http://andrzej-banach.eu

http://culture.pl

http://kresy24.pl

http://minsk.msz.gov.pl

http://nowe.kresy.pl

http://pmsgrodno.org

http://polaki.org

http://wid.org.pl

http://www.krajoznawcy.info.pl

http://www.polskieradio.pl

http://wpolityce.pl

http://znadniemna.pl

\section{ABSTRACT}

Through the centuries, history united Poland and Belarus, therefore Belarus was almost completely Polonized. The history events and border moving of both nations caused that Poles are second biggest national minority after Russians on the Belarusian ground. The general theme of this article is to present testaments of culture that show evidence of Poles' presence on these lands in the form of memorial sites and their current activities in Belarus.

Keywords: Poland, Belarus, national minority, memorial sites, cultural heritage 